\title{
Review of Political Party and Empowerment Preaching
}

\author{
Nia Kurniati Syam \\ Faculty of Dakwah \\ Universitas Islam Bandung \\ Bandung, Indonesia \\ nia_syamday@yahoo.com
}

\begin{abstract}
Indonesia is one of the countries that embraces democratic governance system with multiparty model and has specific law for party system. In every opportunity before the election, whether election for president, governor or mayor, party laws is always reviewed. The last one is law number 2 in 2008 which regulates the formation of political parties, objectives, functions, rights and obligation of political parties. Based on their affiliation of the parties in Indonesia, they are diverse, some are based on socialist, democratic, and religion. Those situation inspired to analyze how the politicians affiliated in religion are able to empower the preaching role in a society assuming that this can influence on the sustainability of the society massively. The aim of this research is identify the empowerment preaching of the politicians. The analysis has been conducted based on the current political situation and existing political publication. The results show that there are challenges for the political parties to empower the preaching. Preaching can contribute to the regulations such as government and regent regulations. The spirit of politicians struggling in parliament could realized chapters which have been formulated based on the preaching spirit. One of the government regulations of West Java Province concerning The Northern Bandung Region in using the lands to build some luxurious houses under one condition that is there must be convenient house for worship, other regulations are: the policy of the government towards alcoholic beverages or liquors, gambling and the so forth.
\end{abstract}

Keywords-empowerment of preaching; Islamic way of life; politics parties.

\section{INTRODUCTION}

Our society has the impression of a lack of positive response to political activities, as if politics contain cunning, hypocrisy, blind ambition, betrayal, deception, and other bad connotations attached. Sometimes people hold that politics is not associated with religious morality at all. An example of "Kyai politician", who claimed that if politician moved from one party to another party, they demonstrated that politics is a world affair and clearly the life of the world is just play and play games. Otherwise, God already said in the Qur'an, "Wa ma hadzihil hayatuddunya illa lahwun wa la'ib", which clarify that this world nothing but a play and a mere game?

The perception of such politicians is dangerous, in terms of the preaching of da'wah, such political views are also detrimental. As current situation show, that some political activities such as political demonstration, legislative debates, evaluation process of political laws, political campaigns, political discussions in some university, training of party candidates and their empowerment. This situation described that politics were less attractive and people would avoid them. Otherwise some people have more interest to participate actively in public policy institutions, including member of Da'wah faculty at Universitas Islam Bandung. The analysis has been conducted in two aspects, role of political party and how to empower da'wah in Indonesia.

\section{RESEARCH METHOD}

The research method has been used is case study through data collection technique of study documentation and direct interview to 10 people legislator in West Java.

\section{RESULTS AND DISCUSSION}

The model of political parties were born in western Europe due to two forces, the first was parliament in the form of elitist groups established to defend the position of the king, and the second was political parties born outside parliament that rely on certain ideologies or worldviews, such as socialism, christian democrats, and others [1]. According to the Indonesia's law no 31 of 2002 described that political parties are political organizations formed by a group of citizens, who are voluntarily and equality basis and they have objectives to achieve the interests of members, society, nation and state through the election general."

Several subject matter experts have described about political parties, such as:

Political party is an organization that attempts to achieve and maintain control of government [2]. A political party is a coalition of fairly stable, enduing, and frequently conflicting interests, organized to mobilize support in competitive election in order to control policy making [3]. Political party is an organized group whose members have the same orientation, values, and goals. The goal of this group is to gain political power to seize political positions in a constitutional way to implement general policies [1].

Based on some various definitions of political party we could concluded that there were at least three basic principles 
of political party. The first is a party as a coalition, such as forming coalitions of various interests to build a major of political power. A party has been formed on the basis of the coalition of their political group in parliament. An example by Golkar party, there are several groups, such as Kosgoro, MKGR and Korpri (before 1999), by PPP there are several groups such as NU, Parmusi, Perti and PSII. The existing group within this large party often disrupt the unity of the party due to each other seeks to become dominant in terms of determining the principles of struggle, program, stewardship and candidacy. The second is a party as an organization, it will be sustainable, dynamic through their organization. Political parties have to be supervised so that they will be able to struggle, and represented large number of people or groups. The political parties have to nominate members for elections, nominate an agreed candidate, raise funds, and create campaign. Political parties have to mobilize their members to be loyal to the party. The third is a party as policy maker. Political parties are also different from other social groups in taking policy. Political parties have proposed candidates for public officer. They have to encourage power to influence or determine officers or employees as government official, even they have to participate in the policy-making in ministries where cadres occupy the same position through party collectivity [4].

Parties can be distinguished between political parties, political movements (movement) and pressure groups. Movement is a group or group that wants to change, or create a new community institution using political means. This movement is limited and more fundamental, and sometimes ideological. Binds its members so that Mapu fosters a strong group identity. A movement has an organization that is less powerful than a political party, and may say never organize itself to contest elections. Pressure group or better known as the interest group. The group strives for an interest and gives influence to the political forces in parliament for a favorable decision and avoids adverse decisions that this pressure group strives to influence holders of positions in government positions and provide support to candidates proposed by parties as they exist interests. For example the ministry, director general or director of the State Owned Enterprise (SOE/BUMN).

Politics is one tool of da'wah. Etymologically, the word "da'wah" comes from Arabic in the form of "masdar" from the word " $d a^{\prime} a-y a d ' u$ ". It means calling, inviting, praying, and propaganda [5]. Understanding da'wah in terms of language means also invite, calling is calling with a goal to encourage someone to implement certain ideals.

In QS. Joseph: 108, Allah taught the prophet Muhammad (peace and blessings of Allah be upon him) to call upon mankind in the way of Allah. In calling mankind to the way of Allah the Prophet and his followers rely on clear explanations ("bashirah") and while praising the holiness of God, the Prophet explained that he is not classified as polytheists. Da'wah in this verse is "ad-dakwah ila Allah (ad'u ila Allah)", such as invitations, calls, and appeals to God.

Sticking to the Qur'an, the creation of man in the world is to be the "khalifah" of Allah, who is in charge of managing the life of the world according to the will of God. Moslem people have a dynamic and creative role to carry out the task of the caliphate. Armed with religion, rationality, and free will, he is expected to be able to solve the problems he faces by making the Qur'an and "Sunnah" as a "term of reference" paradigm. In the task of the caliphate the "da'wah" became the most essential part because the development of man and society as the will of Allah the Creator ("al-Khaliq") can only be held if individually and collectively, people and society are willing to welcome "da'wah ila Allah" and spreading good deeds (every effort, work and action of virtue) into society.

The "da'wah" which contains the "amar ma'ruf" and "nahyi munkar" driven by the moslem people (Surah Al-Imran: 104) is in fact facing the "amar ma'ruf" done by the hypocrites (Surat At-Taubah: 67). Confrontation between the "ma'ruf" and the "munkar", between the " $d a$ 'wah" that invites people not to become 'ashabul nar' does make the life of mankind is full of struggle, and struggle. Islamic " $d a$ 'wah" activities, in fact covering all dimensions of human life, since "amar ma'ruf" and "nahyi munkar", also covers all life activities. Thus, cultural, political, economic, social, etc. activities can be used as "da'wah" activities; both "da'wah Islamiyah (da'wah ila Allah)" and "dakwah jahiliyah", namely the "da'wah" that makes hell as the final place ("da'wah ila an-nar").

According to Mohammad Al-Naquib Al-Attas quoted in the book "Ijtihad" Politics states, described that Islamization is the process of human liberation, first of all magical, mythological, animistic and irrational national cultural traditions, then it also means human liberation from the secular influence that shackles his thinking and his behavior [6].

A political moslem figure (communicator) can make politics as a tool of "da'wah", an opportunity to fight for ideology since it is very possible to change the product of decision making and law making, either governor regulation, regional regulation which will impact to public. In accordance with the functions of board members are budgeting, controlling, legislating. Moslem senators have to compete to supervise the budget, they have control function on the laws that will apply to societies with their moral and spiritual responsibilities.

Tawheed as axis (Islamic axis) for all Islamic teachings propagate " $d a$ 'wah" activities to realize freedom to human beings from the trappings of nativism, which invites people back to the teachings of the ancestors even though these teachings are irrational, animistic, Movements in various areas of life simultaneously to change the status quo so that Islamic values have a chance to thrive, for the happiness of all humanity. Change itself can be either reformative or revolutionary, depending on the social, political, economic, and psychological situation of a society. Reductive changes of the legislative members, so that da'wah activities in any field is designed in accordance with the conditions of Indonesian society, including the making of law. Tawheed as axis (Islamic axis) all Islamic teachings propagate "da'wah" activities to free human beings from the trappings of nativism, which invites people back to the teachings of the ancestors even though these teachings are irrational, animistic issues etc. Movements in various areas of life simultaneously to change the status quo so 
that Islamic values thrive, for the happiness of all humanity. Change itself can be either reformative or revolutionary, depending on the social, political, economic, and psychological situation of a society. Reductive changes of the legislative members, so that da'wah activities in any field is designed in accordance with the conditions of Indonesian society, including the developing of law.

Tawheed as the spirit of "dakwah" encourages members of the legislature to reconstruct socially in accordance with the teachings of Islam. In other words, the legislative members carry out the "da'wah" that is monotheistic concealed constantly seeking to popularize Islam, in the view of life, and as the paradigm of solving every problem arising in modern society with all its manifestations. This invitation is certainly voluntary as the answer to the call of Tawheed depends entirely on the man himself, whether they want to believe or kufr, according to the word of Allah (QS Al-Kahf: 29 described "And speak, the truth comes from your Lord, who may believe, and whoever may not believe ("kufr")".

All areas of our life could be corporate with " $d a^{\prime} w a h$ " and all activities of human life could be used as tools of " $d a$ 'wah". Political activities, as well as economic activities, social efforts, cultural movements, science and technology activities, art creations and codification of law etc., should indeed be a tool for empowering moslem people, therefore political activity is one of the activities of our life is quite important, considering a society can only live regularly if the people live and live in a country with all the power of its power. Thus the importance of political role in modern society, because politics greatly determine the social, economic, political, cultural, legal, and various other aspects of life. Likewise, politicians in West Java in determining legal formal to rescue the development of jail in Jabar society especially in the law of means of worship on housing and drinking laws.

\section{CONCLUSION}

Politics is one of tools to achieve the goals of democratic interests in the state. Through the politics of one of the moslem politicians to carry out their "da'wah", through empowerment of preaching in any field must be sourced from monotheism, so the morals and ethics of moslem politicians have to rely on "tawheed". Functional politics towards to the empowerment of preaching is a politics that fully heed the values of Islam. In this connection it should be noted that the Islamic political life does not provide a place for secularization, although secularisation is regarded as a process that can not but accompany modernization.

\section{REFERENCES}

[1] Budiardjo, Miriam. Pro, Dasar-Dsar Ilmu Politik. Jakarta: PT Gramedia Pustaka Utama, 2002.

[2] Carr, Robert K- Marver H. Bernstein- Walter F. Murphy, American Democracy in Theory and Practice: Essentials of National, State, and Local Government. New York: Holt Rinehart and Winston. Inc., 1965.

[3] D. Nimmo, Komunikasi Politik. Bandung: Rosdakarya, 2000.

[4] H. Cangara, Komunikasi Politik: Konsep, Teori dan Strategi. Jakarta: Rajawali Pers. 2011.

[5] A. Subandi, Ilmu Dakwah Pengantar Kearah Metodologi. Bandung: Yayasan Syahida, 1994.

[6] A. Rais, Majalah Pandji Masyarakat no. 529. 1993. 